\title{
Helikaurolides A-D with a Diterpene-Sesquiterpene Skeleton from Supercritical Fluid Extracts of Helianthus annuus L. var. Arianna
}

\author{
Ascensión Torres, ${ }^{\dagger}$ José M. G. Molinillo, ${ }^{\dagger}$ Rosa M. Varela, ${ }^{\dagger}$ Lourdes Casas, ${ }^{\ddagger}$ Casimiro Mantell, ${ }^{\ddagger}$
} Enrique J. Martínez de la Ossa, ${ }^{\dagger}$ and Francisco A. Macías ${ }^{*}{ }^{\dagger}$

${ }^{\dagger}$ Allelopathy Group, Department of Organic Chemistry, Institute of Biomolecules (INBIO) and Department of Chemical Engineering and Food Technology, Campus de Excelencia Internacional (ceiA3), Faculty of Science, University of Cadiz, C/República Saharaui 7, 11510 Puerto Real, Cádiz, Spain

\section{Supporting Information}

ABSTRACT: Four novel compounds (1-4) with an unprecedented skeleton that combines a sesquiterpene lactone and a kaurane diterpene acid were isolated from Helianthus annuus $\mathrm{L}$. var. Arianna extract, which was obtained under supercritical conditions. The structures of 14 were elucidated by NMR and MS analyses. The biosynthetic routes involve sesquiterpene lactones and kauranic acid, both of which were previously isolated from this species.

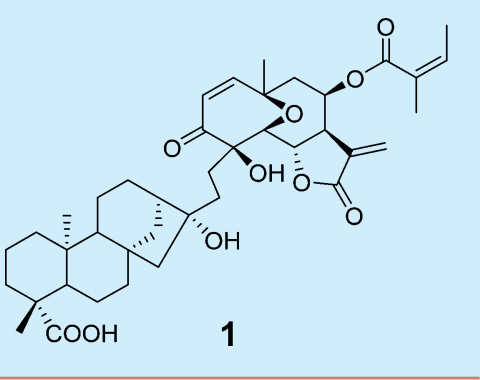

$\mathrm{W}$ e recently published a phytochemical study of a supercritical fluid extract (SFE) of Helianthus annuus L. var. Arianna obtained under conditions selected by bioactivity and yield. ${ }^{1}$ The extract afforded 52 substances that belonged to 10 different chemical classes, which were mainly sesquiterpene lactones, diterpenes, and flavonoids. Four new compounds were described for the first time. The SFE technique proved to be a useful tool to obtain bioactive extracts that contained a number of bioactive compounds from this cultivar. Four additional compounds were subsequently isolated, but their structures appear to be very different from those previously identified.

We report here the isolation and structural elucidation of compounds 1, 2, 3, and 4 from the leaves of $H$. annuus L. var. Arianna collected in June 2009 during the third growth stage of the plant. $^{2}$ SFE extraction was carried out in the same way as the study outlined above, and the method is described in the Supporting Information. The dried extract $(7.0 \mathrm{~g})$ obtained by the fractionation process (SFE) was chromatographed to afford compounds 1-4, all of which have an unprecedented skeleton that combines a sesquiterpene lactone and a kaurane diterpene acid (Figure 1). There are many recent reports where kaurane diterpenes $^{3}$ and sesquiterpene lactones ${ }^{4}$ are isolated from sunflowers and their biological properties tested.

Compound 1 appeared to be a mixture of a sesquiterpene lactone and a kaurane diterpene. After numerous attempts to separate the two compounds, we decided to acquire a mass spectrum, which contained a molecular ion peak at $\mathrm{m} / \mathrm{z}$ 695.3793. This mass is consistent with the molecular formula $\mathrm{C}_{40} \mathrm{H}_{54} \mathrm{O}_{10}$ (calcd for $[\mathrm{M}+\mathrm{H}]^{+}$695.3795). Thus, compound $\mathbf{1}$ is not a mixture but a single compound with two well differentiated halves.

The sesquiterpenoid half gave very similar ${ }^{1} \mathrm{H}$ and ${ }^{13} \mathrm{C}$ NMR spectra to those of helivypolide L, which was previously

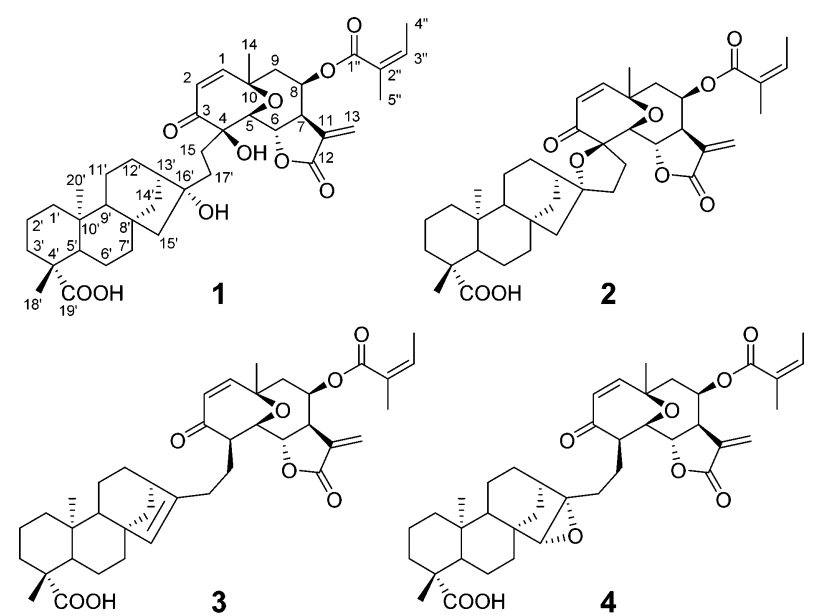

Figure 1. Structures of Helikaurolides A-D (1-4).

isolated from sunflower extracts. Together with differences in the chemical shifts of the H-5 and H-6 signals, the main difference was the absence of $\mathrm{H}-15$ as a hydroxymethylene group, which led us to consider that the union between the two structures was at $\mathrm{C}-15$. The HMBC spectrum allowed us to assign $\mathrm{H}-15$ at $\delta_{\mathrm{H}} 2.02$ (Table 1). Differences between the ${ }^{13} \mathrm{C}$ NMR spectra were also observed for chemical shifts corresponding to C-4 and C-15 ( $\delta_{\mathrm{C}} 82.5$ and 28.4 , respectively)

Regarding the diterpenoid half, the spectroscopic data were very similar to those of $16 \alpha$-hydroxy-ent-kauran-19-oic acid, except for the signal of C-17' $\left(\delta_{\mathrm{C}} 29.9\right.$ for 1 and $\delta_{\mathrm{C}} 24.4$ for

Received: July 30, 2015

Published: September 14, 2015 
Table 1. NMR Spectroscopic Data for Compounds 1-4

\begin{tabular}{|c|c|c|c|c|c|c|c|c|}
\hline \multirow[b]{2}{*}{ no. } & \multicolumn{2}{|l|}{1} & \multicolumn{2}{|l|}{2} & \multicolumn{2}{|l|}{3} & \multicolumn{2}{|l|}{4} \\
\hline & $\delta_{\mathrm{H}}$ multi $(J \text { in } \mathrm{Hz})^{a, c}$ & $\delta_{\mathrm{C}}^{b}$ & $\delta_{\mathrm{H}}$ multi $(J \text { in } \mathrm{Hz})^{a, c}$ & $\delta_{\mathrm{C}}^{b}$ & $\delta_{\mathrm{H}}$ multi $(J \text { in } \mathrm{Hz})^{a, c}$ & $\delta_{\mathrm{C}}^{b}$ & $\delta_{\mathrm{H}}$ multi $(J \text { in } \mathrm{Hz})^{a, c}$ & $\delta_{\mathrm{C}}^{b}$ \\
\hline 1 & $6.24 \mathrm{~d}(13.1)$ & 146.8 & $5.79 \mathrm{~d}(10.5)$ & 136.0 & $6.24 \mathrm{~d}(13.2)$ & 149.7 & $6.24 \mathrm{~d}(13.1)$ & 146.8 \\
\hline 2 & $6.01 \mathrm{~d}(13.1)$ & 126.4 & $5.54 \mathrm{~d}(10.5)$ & 126.0 & $5.84 \mathrm{~d}(13.2)$ & 126.8 & $5.84 \mathrm{~d}(13.1)$ & 126.7 \\
\hline 3 & & 202.3 & & 207.7 & & 202.3 & & 202.3 \\
\hline 4 & & 82.5 & & 77.8 & $2.93 \mathrm{ddd}(7.2,2.3)$ & 55.9 & $2.88 \mathrm{dq}(1.5)$ & 56.0 \\
\hline 5 & $4.13 \mathrm{~d}(9.8)$ & 81.7 & $4.21 \mathrm{~d}(7.6)$ & 76.4 & $4.05 \mathrm{dd}(2.3,9.7)$ & 75.8 & $4.03 \mathrm{dd}(1.5,7.8)$ & 75.6 \\
\hline 6 & 5.03 dd $(9.8,9.7)$ & 75.6 & $4.81 \mathrm{dd}(7.6,10.5)$ & 79.2 & 4.99 dd $(9.7,9.9)$ & 76.4 & 4.96 dd $(7.8,9.4)$ & 76.1 \\
\hline 7 & $\begin{array}{l}3.42 \text { dddd }(9.7,1.9,3.0 \text {, } \\
3.5)\end{array}$ & 47.7 & $\begin{array}{l}3.50 \text { dddd (10.5, 2.9, 3.5, } \\
1.4)\end{array}$ & 46.0 & $\begin{array}{l}3.40 \text { dddd }(9.9,1.4,3.1 \\
3.3)\end{array}$ & 46.8 & $\begin{array}{l}3.40 \text { dddd }(9.4,1.9,3.0 \text {, } \\
3.5)\end{array}$ & 47.1 \\
\hline 8 & 5.76 ddd $(1.9,2.8,3.9)$ & 65.4 & 5.67 ddd $(2.8,2.1,1.4)$ & 65.8 & 5.76 ddd $(1.4,2.7,2.9)$ & 65.4 & 5.76 ddd $(1.9,2.8,3.9)$ & 65.5 \\
\hline 9 & $2.11 \mathrm{dd}(15.3,2.8)$ & 46.1 & $2.07 \mathrm{dd}(16.0,2.8)$ & 45.2 & $2.13 \mathrm{dd}(15.4,2.7)$ & 46.9 & $2.12 \mathrm{dd}(15.3,2.8)$ & 46.9 \\
\hline & $2.31 \mathrm{dd}(15.3,3.9)$ & & $1.97 \mathrm{dd}(16.0,2.1)$ & & $2.34 \mathrm{dd}(15.4,2.9)$ & & $2.32 \mathrm{dd}(15.3,3.9)$ & \\
\hline 10 & & 80.9 & & 74.6 & & 80.9 & & 80.9 \\
\hline 11 & & 133.7 & & 135.6 & & 134.5 & & 134.4 \\
\hline 12 & & 168.2 & & 169.6 & & 168.5 & & 168.4 \\
\hline 13 & $5.64 \mathrm{~d}(3.0)$ & 122.6 & $5.53 \mathrm{~d}(3.5)$ & 120.4 & $5.62 \mathrm{~d}(3.1)$ & 122.0 & $5.62 \mathrm{~d}(3.0)$ & 122.4 \\
\hline & $6.32 \mathrm{~d}(3.5)$ & & $6.22 \mathrm{~d}(2.9)$ & & $6.30 \mathrm{~d}(3.3)$ & & $6.30 \mathrm{~d}(3.5)$ & \\
\hline 14 & $1.41 \mathrm{~s}$ & 32.8 & $1.31 \mathrm{~s}$ & 30.0 & $1.45 \mathrm{~s}$ & 31.7 & $1.44 \mathrm{~s}$ & 31.8 \\
\hline 15 & $2.02 \mathrm{~m}$ & 28.4 & $\begin{array}{l}2.75 \text { ddd }(19.5,3.5,7.7) \\
2.60 \text { ddd }(19.5,2.9,8.4)\end{array}$ & 33.0 & $1.97 \mathrm{~m}$ & 28.6 & $1.89 \mathrm{~m}$ & 26.4 \\
\hline $1^{\prime \prime}$ & & 166.1 & & 166.3 & & 166.2 & & 166.2 \\
\hline $2^{\prime \prime}$ & & 125.9 & & 127.0 & & 126.4 & & 126.5 \\
\hline $3^{\prime \prime}$ & $6.12 \mathrm{qq}(7.2,1.5)$ & 141.2 & $6.12 \mathrm{qq}(6.9,1.4)$ & 140.3 & $6.13 \mathrm{qq}(7.3,1.5)$ & 140.6 & $6.12 \mathrm{qq}(7.0,1.6)$ & 141.1 \\
\hline $4^{\prime \prime}$ & $1.96 \mathrm{dq}(1.5,7.2)$ & 15.9 & $1.99 \mathrm{dq}(1.4,6.9)$ & 15.9 & $1.96 \mathrm{dq}(1.5,7.3)$ & 15.4 & $1.94 \mathrm{dq}(1.6,7.0)$ & 15.3 \\
\hline $5^{\prime \prime}$ & $1.79 \mathrm{dq}(1.5,1.5)$ & 20.6 & $1.81 \mathrm{dq}(1.4,1.4)$ & 20.6 & $1.74 \mathrm{dq}(1.5,1.5)$ & 20.4 & $1.76 \mathrm{dq}(1.6,1.6)$ & 20.5 \\
\hline $1^{\prime}$ & $\begin{array}{l}0.78^{*} \mathrm{~m} \\
1.84^{*} \mathrm{~m}\end{array}$ & 39.6 & $\begin{array}{l}0.77^{*} \mathrm{~m} \\
1.82 * \mathrm{~m}\end{array}$ & 40.6 & $\begin{array}{l}0.80^{*} \mathrm{~m} \\
1.86^{*} \mathrm{~m}\end{array}$ & 40.6 & $\begin{array}{l}0.84^{*} \mathrm{~m} \\
1.87^{*} \mathrm{~m}\end{array}$ & 40.7 \\
\hline $2^{\prime}$ & $1.53^{*} \mathrm{~m}$ & 19.0 & $1.45^{*} \mathrm{~m}$ & 19.0 & $1.42 * \mathrm{~m}$ & 19.1 & $\begin{array}{l}1.83 * \mathrm{~m} \\
1.39 * \mathrm{~m}\end{array}$ & 18.9 \\
\hline $3^{\prime}$ & $\begin{array}{l}1.01^{*} \mathrm{~m} \\
2.15^{*} \mathrm{~m}\end{array}$ & 37.8 & $\begin{array}{l}1.01^{*} \mathrm{~m} \\
2.16^{*} \mathrm{~m}\end{array}$ & 38.0 & $\begin{array}{l}1.01 * \mathrm{~m} \\
2.13 * \mathrm{~m}\end{array}$ & 37.9 & $\begin{array}{l}1.01 * \mathrm{~m} \\
2.15 * \mathrm{~m}\end{array}$ & 37.9 \\
\hline $4^{\prime}$ & & 43.6 & & 43.4 & & 43.6 & & 43.6 \\
\hline $5^{\prime}$ & $1.04^{*} \mathrm{~m}$ & 56.9 & $1.03 * \mathrm{~m}$ & 56.7 & $1.04 * \mathrm{~m}$ & 56.0 & $\begin{array}{l}1.23 * \mathrm{~m} \\
1.04 * \mathrm{~m}\end{array}$ & 56.9 \\
\hline $6^{\prime}$ & $1.78^{*} \mathrm{~m}$ & 22.0 & $1.81^{*} \mathrm{~m}$ & 22.9 & $1.77 * \mathrm{~m}$ & 22.3 & $\begin{array}{l}1.63 * \mathrm{~m} \\
1.79 * \mathrm{~m}\end{array}$ & 20.6 \\
\hline $7^{\prime}$ & $\begin{array}{l}1.41^{*} \mathrm{~m} \\
1.61 * \mathrm{~m}\end{array}$ & 42.0 & $\begin{array}{l}1.54 * \mathrm{~m} \\
1.39 * \mathrm{~m}\end{array}$ & 42.3 & $\begin{array}{l}1.55^{*} \mathrm{~m} \\
1.51^{*} \mathrm{~m}\end{array}$ & 39.5 & $\begin{array}{l}1.42 * \mathrm{~m} \\
1.74 * \mathrm{~m}\end{array}$ & 35.7 \\
\hline $8^{\prime}$ & & 44.6 & & 44.4 & & 49.0 & & 43.2 \\
\hline $9^{\prime}$ & $0.96^{*} \mathrm{~m}$ & 55.9 & $0.95 * \mathrm{~m}$ & 55.9 & $0.99 * \mathrm{~m}$ & 47.9 & $1.14 * \mathrm{~m}$ & 49.5 \\
\hline $10^{\prime}$ & & 40.5 & & 39.6 & & 39.8 & & 39.4 \\
\hline $11^{\prime}$ & $1.55^{*} \mathrm{~m}$ & 18.6 & $1.59^{*} \mathrm{~m}$ & 18.3 & $2.03 * \mathrm{~m}$ & 20.8 & $1.50 * \mathrm{~m}$ & 18.4 \\
\hline $12^{\prime}$ & $1.63^{*} \mathrm{~m}$ & 26.2 & $\begin{array}{l}1.51^{*} \mathrm{~m} \\
1.57^{*} \mathrm{~m}\end{array}$ & 26.3 & $1.47^{*} \mathrm{~m}$ & 25.4 & $1.55 * \mathrm{~m}$ & 26.2 \\
\hline $13^{\prime}$ & $1.93^{*} \mathrm{~m}$ & 47.1 & $2.18^{*} \mathrm{~m}$ & 45.6 & $2.39 * \mathrm{~m}$ & 43.6 & $2.21 * \mathrm{~m}$ & 36.9 \\
\hline $14^{\prime}$ & $\begin{array}{l}1.61^{*} \mathrm{~m} \\
1.91^{*} \mathrm{~m}\end{array}$ & 37.2 & $\begin{array}{l}1.64^{*} \mathrm{~m} \\
1.89^{*} \mathrm{~m}\end{array}$ & 37.3 & $\begin{array}{l}1.34 * \mathrm{~m} \\
2.03 * \mathrm{~m}\end{array}$ & 43.8 & $\begin{array}{l}1.04 * \mathrm{~m} \\
1.47 * \mathrm{~m}\end{array}$ & 31.9 \\
\hline $15^{\prime}$ & $\begin{array}{l}1.46^{*} \mathrm{~m} \\
1.58^{*} \mathrm{~m}\end{array}$ & 56.1 & $1.53^{*} \mathrm{~m}$ & 53.5 & $5.13 \mathrm{~s}$ & 135.6 & $2.72 \mathrm{~m}$ & 66.9 \\
\hline $16^{\prime}$ & & 81.3 & & 84.5 & & 145.6 & & 64.1 \\
\hline $17^{\prime}$ & $1.70^{c} \mathrm{~m}$ & 29.9 & $\begin{array}{l}2.34 \text { ddd }(16.0,2.9,7.7) \\
2.18 \text { ddd }(16.0,3.5,8.4)\end{array}$ & 27.6 & $\begin{array}{l}2.21 * \mathrm{~m} \\
2.12 * \mathrm{~m}\end{array}$ & 27.6 & $\begin{array}{l}1.70 * \mathrm{~m} \\
2.06 * \mathrm{~m}\end{array}$ & 25.8 \\
\hline $18^{\prime}$ & $1.22 \mathrm{~s}$ & 28.9 & $1.22 \mathrm{~s}$ & 28.8 & $1.24 \mathrm{~s}$ & 28.9 & $1.22 \mathrm{~s}$ & 28.9 \\
\hline $19^{\prime}$ & & 183.0 & & 179.9 & & 183.0 & & 182.1 \\
\hline $20^{\prime}$ & $0.95 \mathrm{~s}$ & 15.5 & $0.93 \mathrm{~s}$ & 15.5 & $0.95 \mathrm{~s}$ & 15.9 & $0.95 \mathrm{~s}$ & 15.8 \\
\hline
\end{tabular}

${ }^{a}$ Measured at $600 \mathrm{MHz}$ in $\mathrm{CDCl}_{3} \cdot{ }^{b}$ Measured at $125 \mathrm{MHz}$ in $\mathrm{CDCl}_{3} \cdot{ }^{c_{*}}=$ Overlapped multiplets. Assignments supported by the HSQC and $\mathrm{HMBC}$ spectra.

$16 \alpha$-hydroxy-ent-kauran-19-oic acid). ${ }^{5}$ This finding could indicate that $\mathrm{C}-15$ of the lactone is bonded to $\mathrm{C}-17^{\prime}$. This hypothesis was confirmed by the HMBC spectrum, where correlations between the signals from the lactone and the 


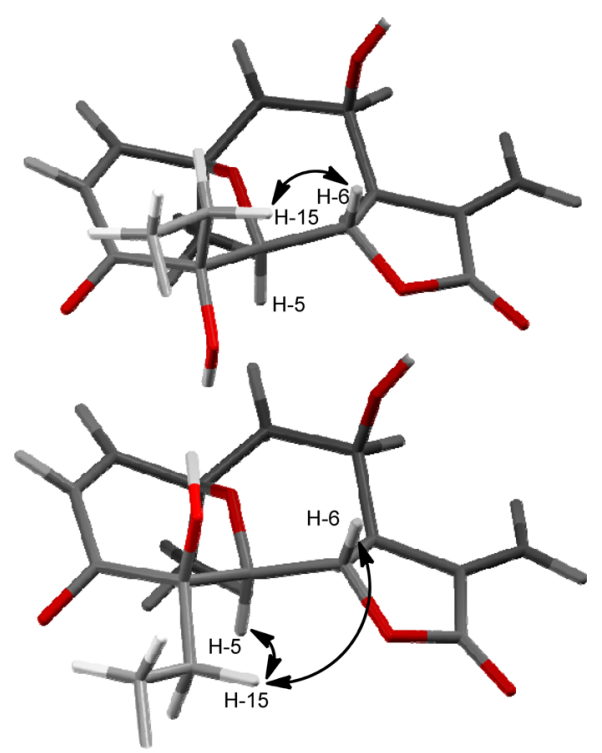

Figure 2. Key NOESY correlations for $\mathbf{1}$.

Scheme 1. Plausible Biosynthetic Pathway for 1 and 2

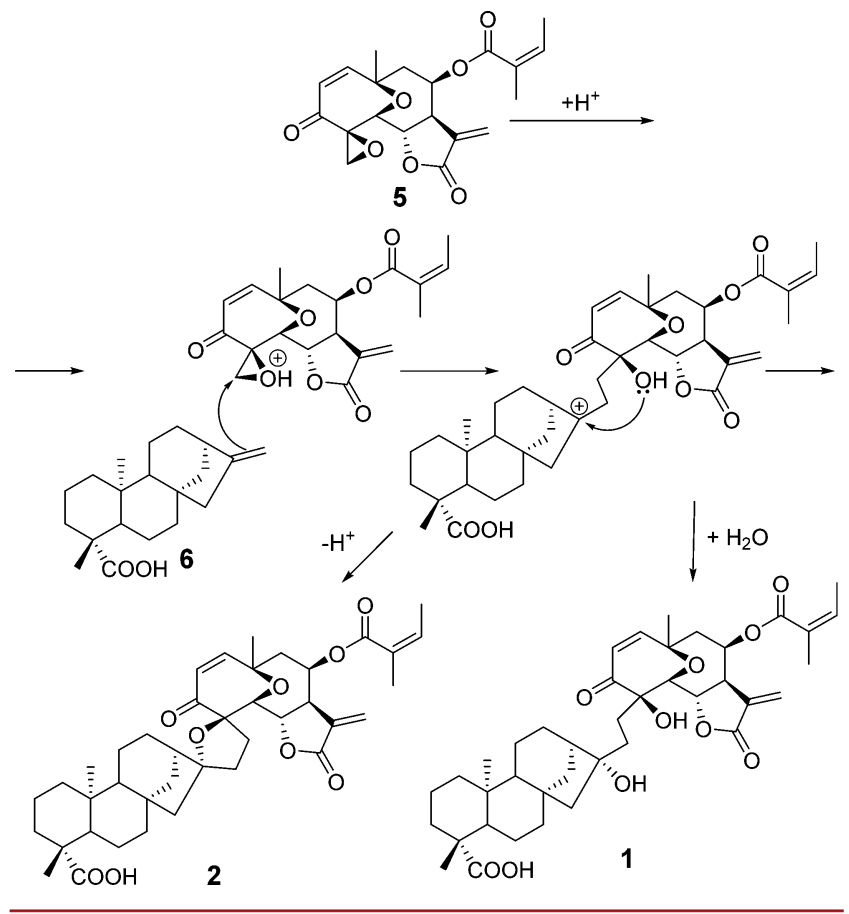

diterpene were observed. Thus, $\mathrm{H}-15$ correlated with C-3, C-4, and $\mathrm{C}-17^{\prime}$, whereas $\mathrm{H}-17^{\prime}$ correlated with $\mathrm{C}-16^{\prime}, \mathrm{C}-15^{\prime}, \mathrm{C}-13^{\prime}$, and $\mathrm{C}-15$.

A ROESY experiment was carried out in an effort to determine the stereochemistry at C-4 of the lactone. H-15 showed correlations with $\mathrm{H}-5$ and $\mathrm{H}-6$. This observation is consistent with a $\beta$-orientation of the hydroxyl group attached to C-4, whereas an $\alpha$-orientation would only correlate with H-6 (Figure 2). Moreover, $\mathrm{H}-17^{\prime}$ from the diterpene showed an effect with H-5 from the lactone. Since a clear NOE was not observed for $\mathrm{H}-17^{\prime}$, the configuration of $\mathrm{C}-16^{\prime}$ was assigned as $\alpha$-hydroxy due to the similarity between the spectrum and that of 16 $\alpha$-hydroxy-ent-kauran-19-oic acid (see Figure 1). This compound was named helikaurolide A (1).
Scheme 2. Plausible Biosynthetic Pathway for 3 and 4<smiles>C=C1CC2C(OC(=O)/C(C)=C/C)CC(C)(C=CC1=O)C1C(=C)C(=O)OC21</smiles>

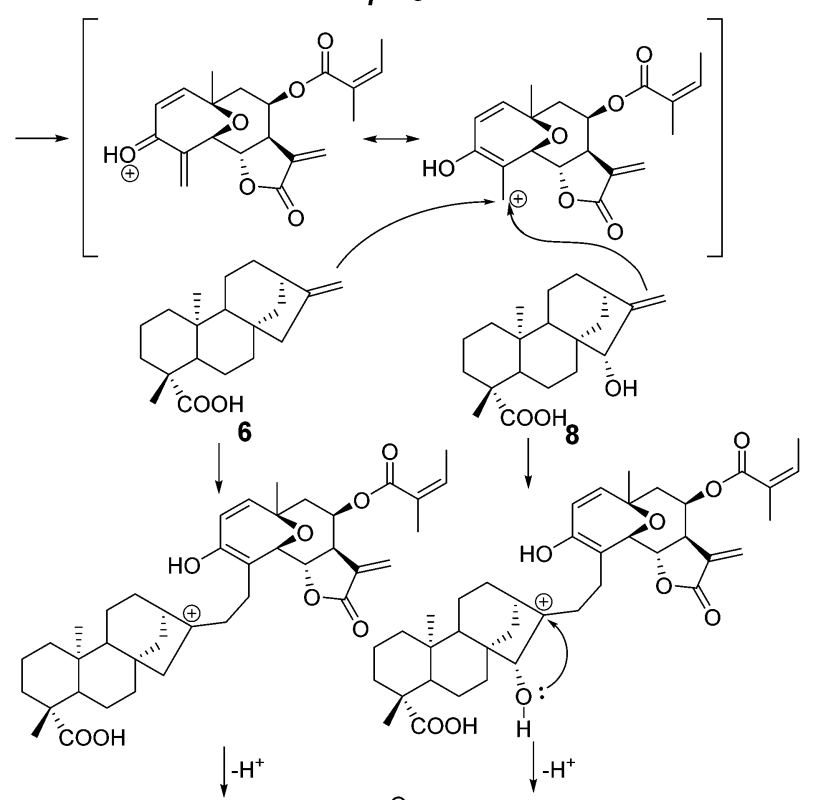

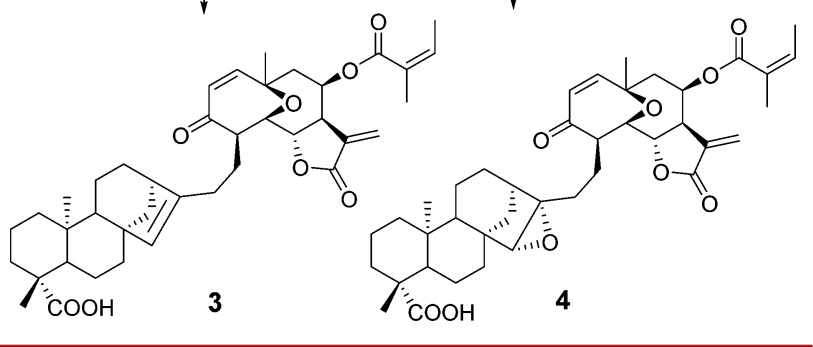

A second compound, helikaurolide B (2), was isolated in a smaller amount $(3.1 \mathrm{mg})$. The HRESI TOF MS of 2 showed a similar molecular formula $\mathrm{C}_{40} \mathrm{H}_{52} \mathrm{O}_{9}(\mathrm{~m} / z$ 677.3701, calcd. for $[\mathrm{M}+\mathrm{H}]^{+}$677.3690), and this is consistent with the loss of a water molecule from 1 . The ${ }^{1} \mathrm{H}$ NMR spectrum was very similar to that of 1 , but some signals appeared to be shielded, especially those assigned to $\mathrm{H}-1(\Delta \delta=-0.45), \mathrm{H}-2(\Delta \delta=$ $-0.47)$, and H-6 $(\Delta \delta=-0.22)$. Nevertheless, the clearest differences were observed for the signals assigned to $\mathrm{H}-15$ and $\mathrm{H}-17^{\prime}$, which were well differentiated and clearly defined. Additionally, COSY and NOESY correlations could be observed between these signals. These data indicated that 2 should be structurally very similar to 1 , but with an oxolane ring constituted by C- 4 and C- 15 from the lactone half and C-16' and $\mathrm{C}-17^{\prime}$ from the diterpene one. This structure was corroborated by the ${ }^{13} \mathrm{C}$ NMR spectrum, which contained analogous signals to 1 , except for those assigned to C-4 $\left(\delta_{\mathrm{C}}\right.$ $77.8 ; \delta \Delta=-4.7), \mathrm{C}-15\left(\delta_{\mathrm{C}} 33.0 ; \delta \Delta=4.6\right), \mathrm{C}-16^{\prime}\left(\delta_{\mathrm{C}} 84.5\right.$; $\delta \Delta=3.2)$, and $\mathrm{C}-17^{\prime}\left(\delta_{\mathrm{C}} 27.6 ; \delta \Delta=-2.3\right)$.

The stereochemistry of $\mathbf{2}$ was identical to that of compound 1, since an NOE was observed between $\mathrm{H}-5$ and protons $\mathrm{H}-15$ and $\mathrm{H}-17^{\prime}$ in the NOESY experiment.

Helikaurolide C (3) (5.4 mg) was isolated as a gum, and its molecular formula was determined to be $\mathrm{C}_{40} \mathrm{H}_{52} \mathrm{O}_{8}$ by HRESI TOF MS on the $[\mathrm{M}+\mathrm{H}]^{+}(\mathrm{m} / z$ 661.3732, calcd. 661.3740). The NMR spectrum contained signals due to a sesquiterpene 
lactone and a kaurane diterpene. The ${ }^{1} \mathrm{H}$ NMR signals were very similar to those of helivypolide $\mathrm{F}(7){ }^{6}$ except for $\mathrm{H}-15\left(\delta_{\mathrm{H}}\right.$ 1.97 for 3 and $\delta_{\mathrm{H}} 4.05$ for 7$)$. Furthermore, the signal assigned to $\mathrm{C}-15$ in the ${ }^{13} \mathrm{C}$ NMR spectrum appeared in the aliphatic carbon region $\left(\delta_{\mathrm{C}} 28.6\right)$ with no heteroatom attached.

The diterpenoid substructure signals were almost identical to those reported for ent-kaur-15-en-19-oic acid and its methyl ester. ${ }^{7,8}$ The main differences were related to the signals corresponding to C-17' $\left(\delta_{\mathrm{C}} 27.6\right.$ for 3 and $\delta_{\mathrm{C}} 15.5$ for ent-kaur15-en-19-oic acid). The union between the two substructures seems to be between $\mathrm{C}-15$ and $\mathrm{C}-17^{\prime}$. This situation was corroborated by an $\mathrm{HMBC}$ experiment, where correlations were observed between $\mathrm{H}-17^{\prime}$ and $\mathrm{C}-15, \mathrm{C}-16^{\prime}$, and $\mathrm{C}-15^{\prime}$. The stereochemistry assigned at $\mathrm{C}-4$ was that shown in Figure 1 since an NOE between $\mathrm{H}-4$ and $\mathrm{H}-5$ was observed in the NOESY experiment.

A small amount $(4.5 \mathrm{mg})$ of helikaurolide D (4) was isolated as a colorless gum. The positive ion mode HRESI TOF MS contained a molecular ion peak at $m / z 677.3697[\mathrm{M}+\mathrm{H}]^{+}$, which is consistent with the molecular formula $\mathrm{C}_{40} \mathrm{H}_{52} \mathrm{O}_{9}$ (calcd for $\left.[\mathrm{M}+\mathrm{H}]^{+}, 677.3690\right)$. The ${ }^{1} \mathrm{H}$ NMR spectrum was essentially the same as that described for compound 3 (Figure 1 ), but with slight differences in some of the chemical shifts. The main differences are due to the deshielding suffered by $\mathrm{H}$ $15^{\prime}\left(\delta_{\mathrm{H}} 2.72 ; \delta \Delta=-2.41\right)$ in the ${ }^{1} \mathrm{H}$ NMR and C-15' $\left(\delta_{\mathrm{C}} 66.9\right.$; $\delta \Delta=-68.7), \mathrm{C}-16^{\prime}(\delta 64.1 ; \delta \Delta=-81.5)$ in the ${ }^{13} \mathrm{C}$ NMR and the shielding observed for the signal corresponding with $\mathrm{C}-17^{\prime}$ at $\delta_{\mathrm{C}} 25.8$. These findings indicate a modification of the double bond at $\mathrm{C}-15$ and $\mathrm{C}-16$ with respect to that in compound 3, namely as an oxirane ring. This structure was confirmed by comparison with the spectrum of ent-15 $\beta, 16 \beta$-epoxykauran-19oic acid, ${ }^{9}$ which was previously isolated from $H$. annuus. ${ }^{1}$ The union of the two substructures between carbons C-15 and C$17^{\prime}$ was confirmed by the correlations between $\mathrm{H}-17^{\prime}$ and $\mathrm{C}$ $16^{\prime}$ and $\mathrm{C}-15$ in HMBC spectrum.

The stereochemistry assigned to C-4 is that shown in Figure 1 , since the NOE between $\mathrm{H}-4$ and protons $\mathrm{H}-5$ and $\mathrm{H}-15$, as well as with $\mathrm{H}-17^{\prime}$, were observed in the NOESY experiment.

Helikaurolides A-D (1-4) represent the first examples of compounds that consist of two substructures: a diterpene and a sesquiterpene lactone. Plausible pathways for this skeleton are shown in Schemes 1 and 2, and they involve starting materials (helivypolides K (5) and F (7), ent-kaur-16-en-19-oic acid (6), and grandifloric acid (8)) that have previously been isolated from extracts of $H$. annuus. ${ }^{1,6}$ There is a great deal of literature concerning reactions in supercritical fluids that do not usually occur under more conventional conditions. ${ }^{10,11}$ To ensure that compounds 1-4 were not formed during the extraction process, we subjected helivypolides $\mathrm{K}$ (5) and $\mathrm{F}$ (7), as well as ent-kaur-16-en-19-oic acid (6), to the same supercritical extraction conditions. After a similar time $(3 \mathrm{~h})$, compound 1, $\mathbf{2}$, or $\mathbf{3}$ could not be detected. This indicates that helikaurolides A-D belong to a family with a new skeleton and they are natural products that are not formed during the extraction procedure.

\section{ASSOCIATED CONTENT}

\section{S Supporting Information}

The Supporting Information is available free of charge on the ACS Publications website at DOI: 10.1021/acs.orglett.5b02221.
General experimental procedures, chemicals, extraction and isolation methods, reaction conditions, and MS, IR, $1 \mathrm{D}$ and 2D NMR spectra for compounds 1-4 (PDF)

\section{AUTHOR INFORMATION}

\section{Corresponding Author}

*E-mail: famacias@uca.es.

\section{Notes}

The authors declare no competing financial interest.

\section{ACKNOWLEDGMENTS}

We gratefully acknowledge the staff at the Rancho de la Merced Research and Formation Center (Junta de Andalucia, Jerez de la Frontera, Spain) for providing the raw material. This research was supported by the Ministerio de Economía y Competitividad (MINECO) (Project AGL2013-42238-R) and Consejería de Economía Innovación y Ciencia, Junta de Andalucia (Project DP12-TEP-725).

\section{REFERENCES}

(1) El Marsni, Z.; Torres, A.; Varela, R. M.; Molinillo, J. M. G.; Casas, L.; Mantell, C.; Martinez de la Ossa, E. J.; Macias, F. A. J. Agric. Food Chem. 2015, 63, 6410-6421.

(2) El Marsni, Z.; Casas, L.; Mantell, C.; Rodríguez, M.; Torres, A.; Macias, F. A.; Martínez de la Ossa, E. J.; Molinillo, J. M. G.; Varela, R. M. J. Supercrit. Fluids 2011, 60, 28-37.

(3) (a) Pugliesi, C.; Fambrini, M.; Salvini, M. Biochem. Genet. 2011, 49, 46-62. (b) Morris, B. D.; Charlet, L. D.; Foster, S. P. J. Chem. Ecol. 2009, 35, 50-57. (c) Macías, F. A.; López, A.; Varela, R. M.; Torres, A.; Molinillo, J. M. G. J. Chem. Ecol. 2008, 34, 65-69. (d) Suo, M. R.; Yang, J. S.; Lu, Y.; Wu, L.; Zheng, Q. T. Chin. Chem. Lett. 2006, 17, $45-48$.

(4) (a) Prasifka, J. R.; Spring, O.; Conrad, J.; Cook, L. W.; Palmquist, D. E.; Foley, M. E. J. Agric. Food Chem. 2015, 63, 4042-4049. (b) Spring, O.; Priester, T.; Stransky, H.; Hager, A. J. Plant Physiol. 1985, 120, 321-329. (c) Rowe, H. C.; Ro, D.-K.; Rieseberg, L. H. PLoS One 2012, 7, e37191. (d) Macías, F. A.; López, A.; Varela, R. M.; Molinillo, J. M. G.; Alves, P. L. C. A.; Torres, A. Tetrahedron Lett. 2004, 45, 6567-6570.

(5) Cai, X. F.; Shen, G.; Dat, N. T.; Kang, O. H.; Lee, Y. M.; Lee, J. J.; Kim, Y. H. Arch. Pharmacal Res. 2003, 26, 731-734.

(6) Macías, F. A.; Fernández, A.; Varela, R. M.; Molinillo, J. M. G.; Torres, A.; Alves, P. L. C. A. J. Nat. Prod. 2006, 69, 795-800.

(7) Hsieh, T.-J.; Wu, Y.-C.; Chen, S.-C.; Huang, C.-S.; Chen, C.-Y. J. Chin. Chem. Soc. 2004, 51, 869-876.

(8) Yamasaki, K.; Kohda, H.; Kobayashi, T.; Kasai, R.; Tanaka, O. Tetrahedron Lett. 1976, 17, 1005-1008.

(9) Gaspar-Marques, C.; Simões, M. F.; Duarte, A.; Rodríguez, B. J. Nat. Prod. 2003, 66, 491-496.

(10) Boyère, C.; Jérôme, C.; Debuigne, A. Eur. Polym. J. 2014, 61, 45-63.

(11) Pollet, P.; Davey, E. A.; Ureña-Benavides, E. E.; Eckert, C. A.; Liotta, C. L. Green Chem. 2014, 16, 1034-1055. 